\title{
Cultural development of the underground urban spaces on the experience of Saint-Petersburg and Harbin
}

\author{
Igor Kirichkov ${ }^{1}$, Svetlana Levoshko, ${ }^{2, *}$ and Olena Oliynyk ${ }^{3}$ \\ ${ }^{1}$ Architectural Design and Research Institute of HIT, Huanhe Road, 73, Harbin,Heilongjiang \\ Province, 150090, China \\ ${ }^{2}$ Scientific Research Institute of the Theory and History of Architecture and Urban Planning,7-ya \\ Parkovaya Str., 21a, Moscow, 105264, Russia \\ ${ }^{3}$ National Aviation University, Kosmonavta Komarova, 1, Kiev, 03680, Ukraine
}

\begin{abstract}
This article is focused on underground architecture design analysis, considering energy efficiency, green technologies, building structure optimization and other questions in Russia (Saint-Petersburg) and China (Harbin). Today, when our society advocatesfor the sustainable development and ecological architecture, the ecotypic underground architecture is an unavoidable theme. There were called some advantages and disadvantages of ecological design implementation methods influence on environment and human behavior. Conclusion based on underground architectural design technologies comparison between contemporary public building construction experience in Russia and China. General plan of the using of underground urban spaces is not existat all, despite the fact that excluding of the same plan forbids any ground construction. There was given a long-time prognosis about underground architecture development - some perspectives and possible results in future.
\end{abstract}

\section{Introduction}

Underground Architecture is one kind of architectural practice that contains a special design and construction solutions for the buildings which are significantly deepened into the earth. The penetration of this kind of buildings may be very deep or partial (one part is significantly deepened; another part is over the earth). According to the A. Tetior, V. Loginov("Design and Construction of Underground Buildings and Structures"), underground buildings are divided on three groups: half-dipped- buildings are located on the side of the ground massif, shallow foundation - less than $10 \mathrm{~m}$. depth, deep foundation more than $10 \mathrm{~m}$. depth.Among the most perceptible examples of the underground architecture are the different temples (underground temples were often used in Christian practice), repositories (underground repositories support a possibility to keep different stuff), stadiums (there are the most ambitious contemporary architecture projects), military

*Corresponding author: s_levoshko@mail.ru 
buildings, etc. Underground Architecture developed for the thousands of years ubiquitously in the world. Perhaps, every country has a specific experience of construction underground buildings[1].

Underground construction in all countries is controlled by specific legislation. The main purpose of this legislation is the relationship between private rights and public interests. The law protects the rights of existing users of land and groundwater, ensure personal safety and health, protection of the natural and cultural environment. One of the complicated legal issues is the restriction of the right of ownership of the underground environment vertically. Underground Architecture is regulated by the CП 42.13330.2011"Urban Development. Urban and Rural Planning and Development" building code in Russia and GB501372011"Code for Classification of Urban Land Use and Planning Standards of Development Land" in China. In a whole, these building codes identify the purpose (function) of a particular city (rural) territory.

Using of the natural forms as the new materials and structures allows create a new unique images of the design object, specify its value and its significance. Architectural volumes "hidden behind the surface" becomes "green" not only on facade, it may appears in interior decoration or exploited roof [2].

Underground engineering relates to the upper class of complexity. It is considered more difficult than the high-rise building, which is increasingly being used for development of large cities. Almost all large cities in the world's have an active process of underground space development, this process is caused by several reasons, at first, the lack of urban areas, second, the rapid growth of population, third, the increasing of air pollution, four, the lack of urban infrastructure development, five, the increasing of traffic density, etc. The consideration of the industrial processes impact on the ecological condition of underground space is necessary during creation of a new underground infrastructure. Underground urban development's characterized by the search for effective forms of investment management, geo-monitoring, improve of safety, properties control, etc.

\section{Russian experience}

\subsection{Café in the Alexander Park Saint-Petersburg}

Architectural studio "Vitruvius and Sons" was formed by students of architecture faculty of Arts of the Russian Academy of I.E.Repin in St. Petersburg in 1994, the first collaboration of association has been participating in exhibitions and architectural student competitions. Professional activities of "Vitruvius and Sons" Architectural Studio launched in 1996[3]. The main activities of the company are: the architectural design of residential and public buildings; the development of urban planning concepts; reconstruction of the building design; interior design; general plan design, etc.

Café in the Alexander Park in Saint-Petersburg was designed by the Architectural Studio "Vitruvius and Sons" in 2003. The project was realized in 2004. Authors of the project areS.Padalko (head of workshop), D. Bykov(general engineer of the project), A. Edovina, O. Shurupova, I. Muthanna, V. Sokolov.

North facade of the building directed towards to the Central Avenue of the park, south Kronversky Channel, western borders with the projected building of family multiplex cinema, eastern is directed to the side of the Alexander Park. The main entrance is located on the west side of the square with the building of the cinema. Entrances to the building of the cafe are provided in accordance with the concept of reconstruction of the Alexander Park. To download the cafe used the service entrance on the eastern facade. Delivery of 
cargo by ramming path from central alley made truck. At the site adjacent to the eastern facade of organized outdoor café(Figure1).

Volume-planning decision is dictated by the placement of the building Café in the context of the reconstructed park and immediate proximity to the projected theater building. Cafe has one level with a variable ceiling height of $3200 \mathrm{~mm}$. in the central part up to 1900 $\mathrm{mm}$. on the flanks. Block kitchen space divides the volume into two relatively independent of the hall, from which views on the cinema building and the Alexander Park.

The building is treated as an integral part of the park, landscape installation (land art). The roof is designed as a lawn, gradually rising from the flanks to the center, so that the north and south facades are earthy masses planted with lawn grass. The western facade is a glass stained-glass window, inscribed in a smooth arc area. Amphitheatre, organized area, is part of the cafe building. Free bend the eastern facade, dictated by the desire to preserve greenery of the park.

For the exterior finish of the building are used: reinforced concrete with traces of formwork, glass with pronounced vertical articulations, lawn grasses.

Landscaping around of the café was decided in a single reception with Alexander Park landscaping and landscaping designed building cinema. Improvement of the building cafe solved bunding, followed by planting lawn grasses and low shrubs. Coverage area of summer cafe, similar coatings packed tracks. The amphitheater, the area at the west facade is made of reinforced concrete with a device hidden illumination.

Technical and economic indicators: construction area $-482.7 \mathrm{~m}^{2}$, total building area $411.6 \mathrm{~m}^{2}$; building volume - $1150 \mathrm{~m}^{3}$; storeys- 1 floor.

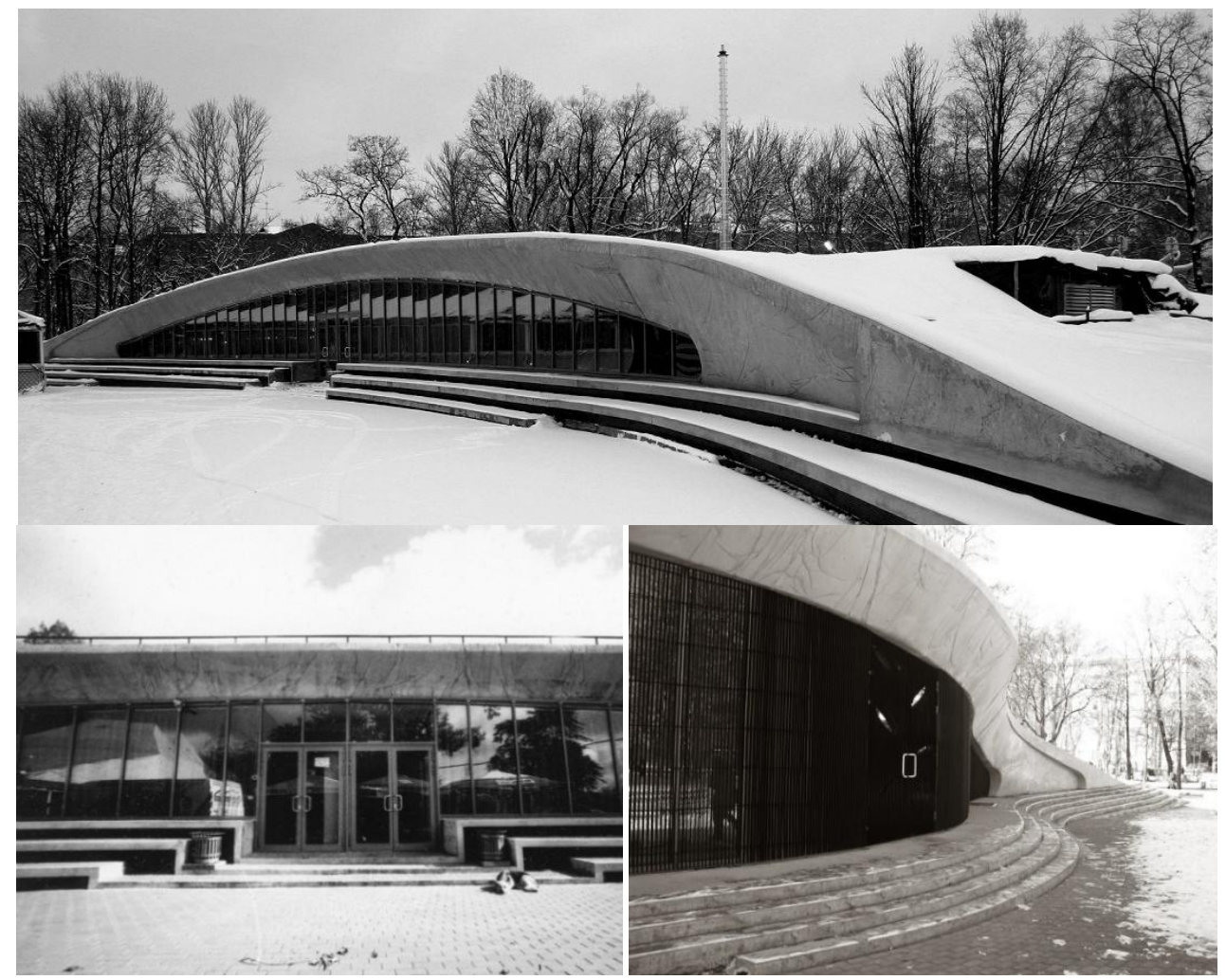

Fig. 1.Café in the Alexander ParkSaint-Petersburg. Architectural Studio "Vitruvius and Sons", 2004. 


\subsection{Royal Beach Cultural and Entertainment Complex of Premium Class}

"Astragal Design"Architectural Studio has been working from 1999. The main directions of Architectural Studio work are the architectural design of residential and public buildings; the development of urban planning concepts; reconstruction of the building design; interior design; general plan design, etc[4].

Authors of the Royal Beach Cultural and Entertainment Complex of Premium Class building project are Shusterman S.V. and FisakD.N.. This cultural and entertainment function building has a sloping landscaped roof. It is situated on the place of previous restaurant structure, which was located at the place until 2009 and destroyed by fire. The architectural solution of the complex was made in the style of "landscape architecture", develops the idea of A.S.Nikolsky to create park pavilions in the form of "inhabited landscape"(Figure 2).

This building has a contemporary deconstructivist forms. Folded form a leafy roof, starting from the ground sheds and projections allow a "merger" of the building with the surrounding landscape, form fit into the environment. Large glass planes, contrasting with the folded roof, provide an opportunity to organize a good overview on the waters of the river Malaya Neva. The structural scheme of the building used metal structures. On top of the roof covering is arranged and landscaped roof waterproofing design. Protecting designs - structural glazing with aluminum profile. The project envisages reconstruction of landscaped area on the northern boundary of the site along the South road, repair of shore protection structures.

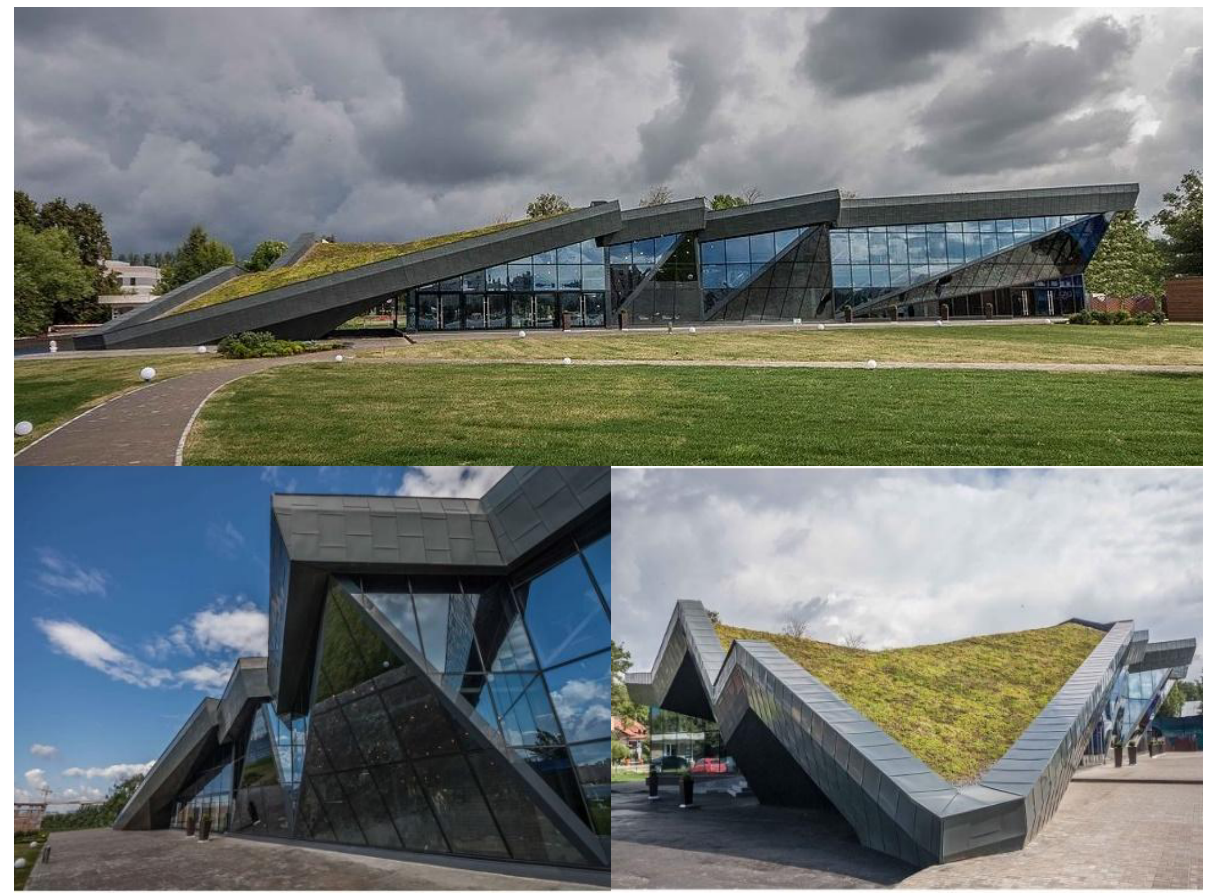

Fig. 2. Royal Beach Cultural and Entertainment Complex of Premium Class in Saint-Petersburg. Architectural Studio "Astragal Design", 2009. 


\section{Chinese experience}

\subsection{Harbin Jun Li Heilongjiang Provincial Museum}

Harbin Jun Li Heilongjiang Provincial Museumis situated in the Dao Li district, Jing Jiang Dong Lu,№66. The museum was opened on 8th January of 2010. It has more than $2700 \mathrm{~m}^{2}$ of exhibition space. There are more than 5000 exhibits, among them a lot of sculptures, primitive dwellings, stuffed animals, old working tools and other valuable things. The represented historical period covers more than one thousand years. In 18th May of 2011 the museum received excellence award, in December of 2012 was assigned the rank of national museum of the first level (Figure3). As researches write, as the architectural design concept of the museum became a special solution to put the building down in the earth, especially to show a specific connection between the old north-east Chinese culture with the fertile soil, because the soil was very important for the life of the ancient people, it helped them to survive and allowed economic growth[5].

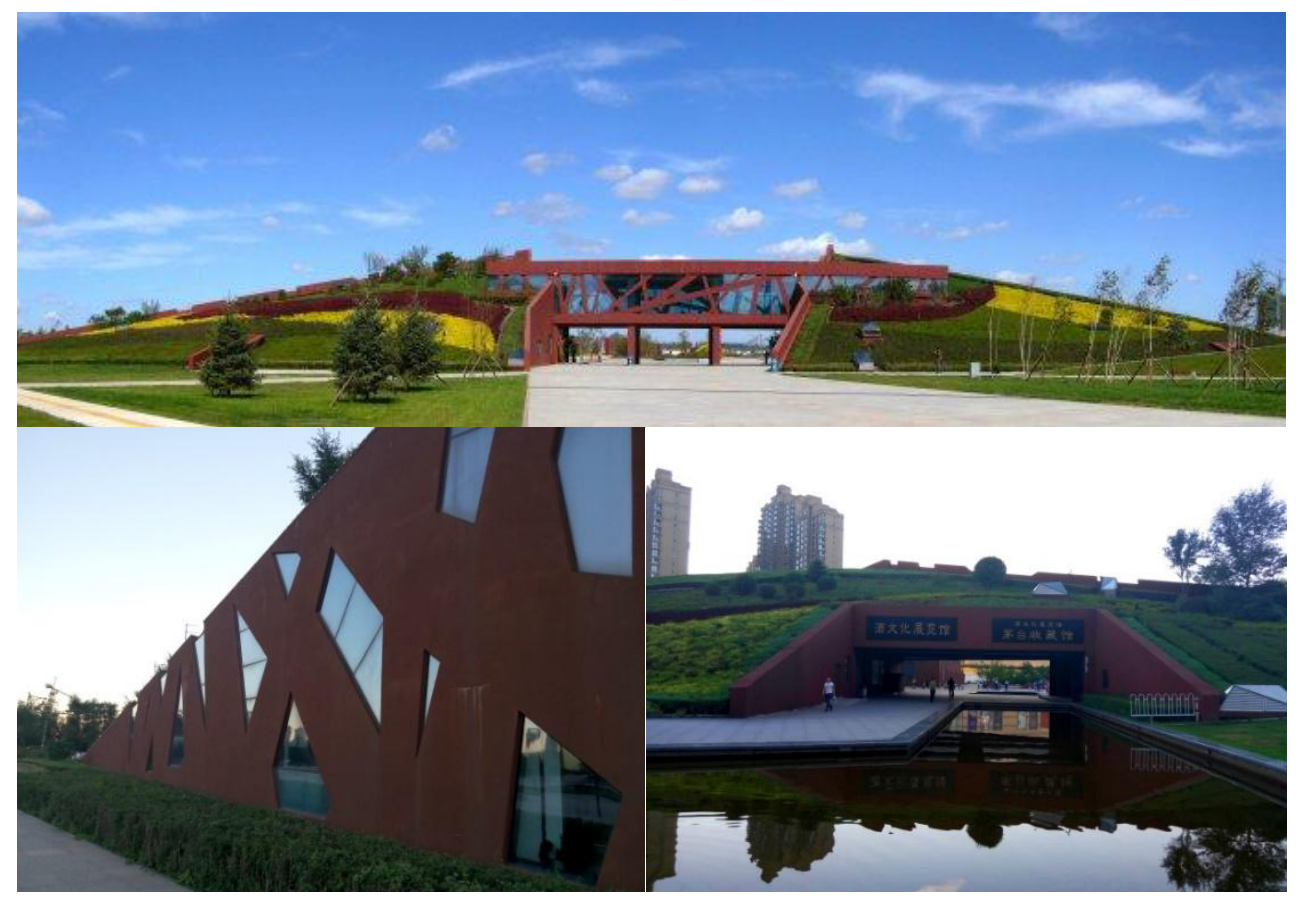

Fig. 3. The Harbin Jun Li Heilongjiang Provincial Museum building,2010.

OneofthepartoftheHarbinJunLiHeilongjiangProvincialMuseumprojectrealizationistheJin HeGarden (Figure4). This garden consists from several parts, covering very big area more than $30000 \mathrm{~m}^{2}$ were given for the landscape design. This design solution symbolizes the Songhua River, which occupies large overflowing areas with sleeves and small ponds. Garden is decorated with numerous bronze sculptures which set among ponds. Very big attention was paid to the green zones - a lot of threes and flowers. Threes and sculptures are reflected into water. It makes a very big impression to the visitors, especially in summer. Chinese landscape specialists are very scrupulously and seriously refer to the scale of environment, people should feel themselves very comfortable being in a different parts of garden. There are very important the points of individual perception. 


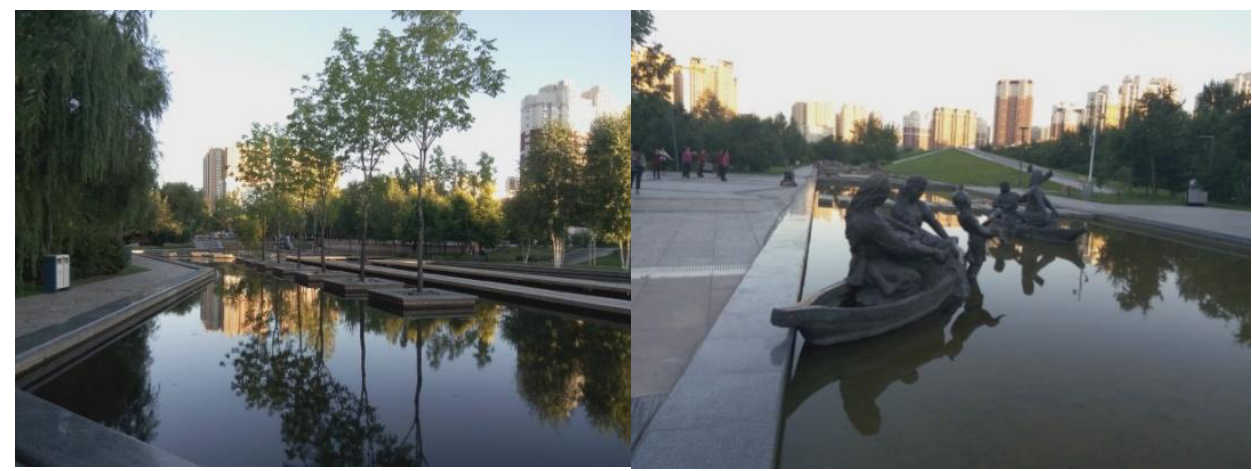

Fig. 4. The Garden of Harbin Jun Li Heilongjiang Provincial Museum: extensive ponds and bronze sculptures. Shallow slope of the turf roof of the museum (on the right), 2010.

One of the most significant structural features of this building is the absence of external visible walls. Building walls are located underground. It has conceptual meaning - the old north-east Chinese culture is open and it doesn't have any barriers. Ancient people were free and kept a nomadic lifestyle. The museum building has monolithic reinforced concrete structure. Covering consists from monolithic reinforced concrete slab, waterproofing layer, fertile ground plane. Actually, fertile ground plane, how it was seen on the field of research, doesn 't have sufficient thickness to serve as effective thermal insulation barrier. It just has $10-15 \mathrm{~cm}$ thickness. Because Harbin is located in a cold climate region, the thickness must be more, presumably $30-40 \mathrm{~cm}$. At this moment Chinese specialists use a certain code for the underground buildings construction - JGJ165 - 2010: Technical Specification for Topdown Construction Method of Underground Buildings.

It should be noted, that the fertile ground covering on the top is a good solution in the whole - for the building structure (it protects building from the wind, rain, low (or very high) temperature, etc.) and also for the urban development (ecological design supports a fresh air, zones for the rest - different human activity, etc.)[6]. But this solution needs a special design for the ventilation system (as the rule, compulsory ventilation systems takes a lot of energy in underground architecture buildings [7-8], insolation (sun rays should go through the walls inside the building, actually it may be achieved by the some small windows on the top, using mirror systems, special light tubes[9]), rain draining system (of course, all rain water can't be absorbed by the plants, so building roof should have a channels going outside), canalization (canalization is a very big problem for underground buildings, because city canalization, as the rule, is self-flowing, it should have a required depth to put dirty water outside, actually, this problem may be decided by partial using of bio toilets), fire proof protection (there are also must be satisfied the fire proof requirements, described into the code) and other equipment[10-11].

\subsection{Harbin Railway Museum}

Harbin Railway Museum is situated near the Sungari river, Dao Li - Dao Wai district, You $\mathrm{Yi} \mathrm{Lu}$ (Figure5). At this moment the museum building is under construction. Construction period was started in 2015, approximately it will be finished to the end of 2016. The construction of Harbin Railway Museum building is one part of the huge project realization, which includes the renovation of historical railway bridge across the Sungari river, construction of sightseeing platform on the north bank of river, Chinese Eastern Railway Park and other objects. Author of this article took an active part in the design of these objects. 
As the design concept of Harbin Railway Museum project became an example of the old Harbin Railway Station, which has been constructed by Russians in the beginning of the XX century. Unfortunately, the old Harbin Railway Station was destroyed many years ago [12]. Another new building was constructed on that place, which doesn't save the style and features of previous historical architecture. The form of facade of the new building (at now Harbin Railway Museum) was designed by the historical photo. Actually, it was a successful example of Russian Modern Style architecture in Harbin.

The structure of Harbin Railway Museum also is very unique. The museum building is situated on the former railways. These railways became not necessary after the construction of the new railway bridge across the Sungari river, completed in 2015. There were decided to keep some part of railways and to construct the new museum building under them. This museum also will be covered by the fertile ground. Different plants will grow here. At most, this covering has decorative function. It is also protect the building from the wind, rain, low (or very high) temperature, etc. - climate factors, provide to the visitors the way on the top (the way to the bridge).

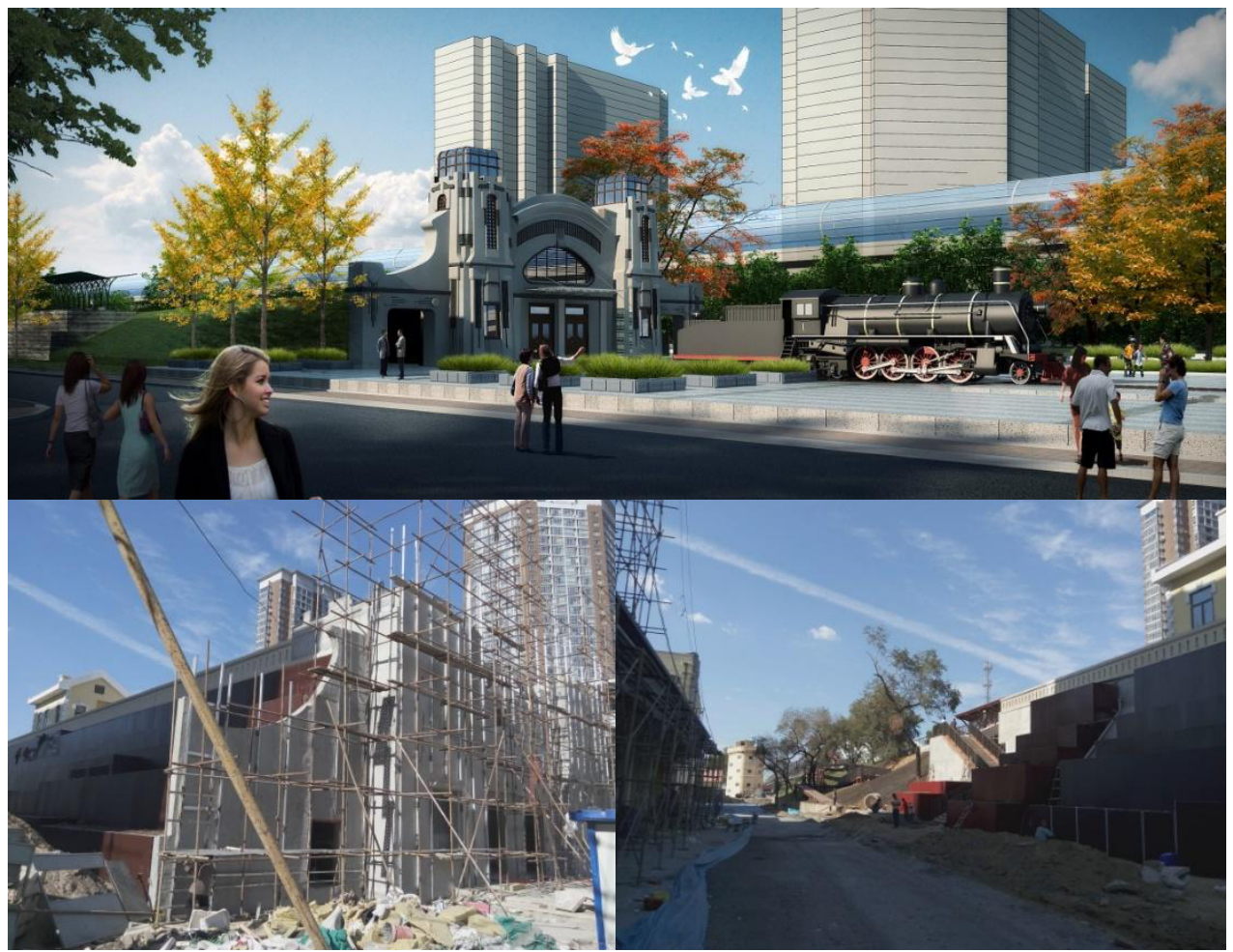

Fig. 5. Harbin Railway Museum Building (design project and photo of building under construction, building will be covered by soil).

The park near the Harbin Railway Museum (official name is Chinese Eastern Railway Park) also occupied a very big territory (Fig. 6). It was decorated by the some artistic compositions (steel structures, painted by the bright red color - often use solution in contemporary Chinese art), green zones (threes, shrubs, flowers, grass). There were installed a several benches. On the whole, there was achieved a very good comfortable space, space that is free from the advertising, supermarkets, parking and another harmful elements for the urban environment. Most likely this place will take a worthy place among the city structure. 


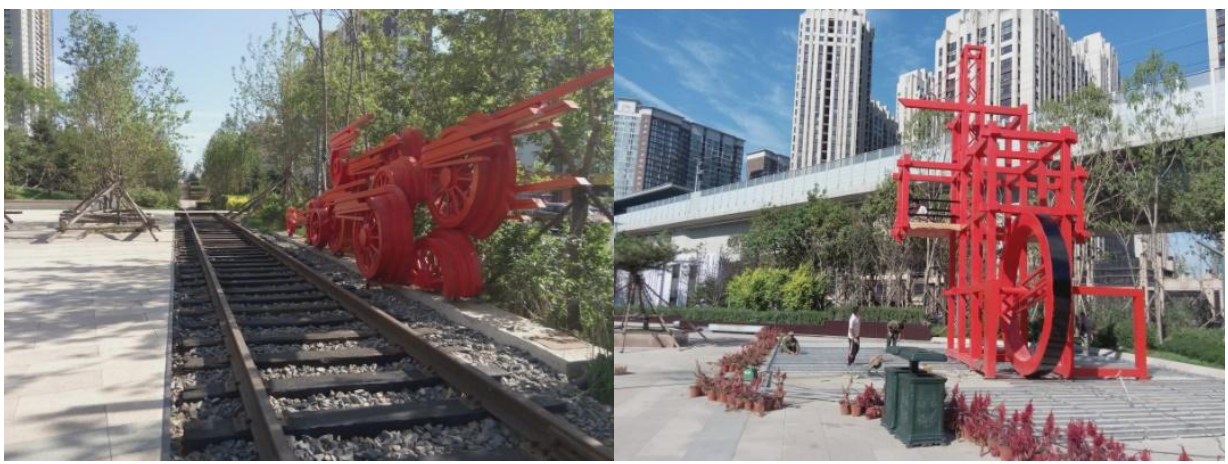

Fig. 6. The Park of Harbin Railway Museum (Chinese Eastern Railway Park),2016.

\section{Experience analysis}

Regarding to the urban planning, contemporary megalopolises cannot be developed without efficient using of underground spaces. Unfortunately, underground architecture development has a local character in Russia and also in China, excepting construction of subway. As a rule, just single projects have a very significant underground space.

The main problem of urban underground space development is the high cost of construction. Investors are often not willing to invest large sums of money in a low payback projects. The function of underground spaces should not be limited by the parking lots, shopping centers. It should be developed by the cultural content: creation of the museums (art galleries), activity centers, theatres, etc. The presence of historic buildings in the city centers also may be considered as the problem of urban underground space development. It is very difficult to construct new buildings under the buildings that already exist.

All underground structures are divided on two construction methods: open method (excavators dig a trench, ditch or a shaft, with creating of the supporting walls) and close method (all construction works occur into the earth - often use a different kinds of drilling machines). Sometimes combined method may be used for the construction, including open and close methods. An example of open construction building method is The Harbin Metro Stations (they are relatively not deep), an example of close construction building method is the metro in Saint Petersburg (Saint Petersburg has a very big soil moisture, so it was necessary to make the metro very deep). Researches recommend to use arch structures for the underground buildings, the load from the earth transfers compression pressure to the low layers more smoothly, also it helps to increase a structure span. Usually, underground structures with the flat ceiling don't exceed $10-15 \mathrm{~m}$, structures in this case should have a colons [13].

Energy efficiency of underground buildings usually depends on the following factors: a location in the ground (receipt of Earth energy, environmental protection), an availability to use solar energy, method of ventilation (an exploitation of warm air return systems), selection of thermal insulation materials, analysis of building function (space arrangement design), consideration of the effect of the nearby buildings, etc.

At this day a lot of green roof technologies have been used in Russia and also in China. One of them is the "German technology of layer cake", which consists from the preventing mechanical damages fiber polyester protective canvas, poly-vinyl-chloride ultra-violet rays resistant shell (PVC), rigid thermal insulation boards with closed pores, substrate protective filtering tissue over the insulation (EnCana, Glanzstott AG ). The peculiarity of this technology is the lack of rain gutters, they are replaced by drainage pipes; also location of the insulation boards - directly on the fiber polyester protective canvas, but not in the 
cavities between the rafters, as it doing in Norway. Due to chemical compatibility with the protective canvas, stepped seams insulation boards (Styrodur, Roofmate) no need a separation layer that simplifies the execution of works. Membrane in rolls is often used as the fiber polyester protective canvas welded with a solvent or a hot air gun. Different forms of aprons are used for the abutting to the walls and apertures. Substrate protective filtering tissue protects the grass covering from the sliding or erosion of the substrate, provides drainage and filtering of the excess water. As the grass covering may be used rolled turf or soil mixture with thickness of $8-10 \mathrm{~cm}$ sowed by the seeds. Estimated load of the covering including thermal insulation boards is $130-150 \mathrm{~kg} / \mathrm{m}^{2}$. Sphagnum peat, expanded clay, perlite and other materials may be added to the soil mixture specially to achieve required properties. The soil mixtureis used in a humidified condition. Irrigation of the grass is recommended only in the dry season. Usually grass no need in mowing, mowing may damage the covering.

The disadvantages of the German green roof technology is that the plant layer thickness of $8-10 \mathrm{~cm}$. serves only a decorative function, but not energy-efficient, synthetic polymeric materials in the covering structure - insulation panels, protective canvas, PVC panels - contradict to the concept of eco-roof.

\section{Conclusion}

As an integrity in the city, the underground architectural space plays more and more important role in the development of a city. In common, considering contemporary experience of underground architecture, there is may be received the next conclusion: underground buildings in Russia and also in Chine don 't have a very deep penetration into the earth - the thickness of ground layer mostly is very small. In order to achieve maximum energy efficiency in a particular case requires thermal calculation, and also calculation of the load. The process of underground urban spaces development is not completed yet.

Creation of complex interactive systems linked to its natural surroundings is impossible without a complete understanding of the objects and phenomena that are typical take place over large areas and linked with the landscape shell. Modern building materials' choice often is been made without understanding of the term "sustainability project". The designed object constructed with implementation of the special materials must be interlinked with the complex interactive system connected to its environment in order to the natural surrounding considering types of the object energy saving properties organization (architectural, landscape and typological) [14-19].

The opportunity of cultural develop of underground urban spaces becomes more useful in the context of post-industrial city development, exemption of the city from industrial spaces. The context of post-industrial development also is ambiguous, which is reflected in the profound transformation of the space. At this day, ignoring of this question has already led to disastrous results on examples of some highly industrialized cities in the past like Detroit, Linz, Manchester, and others. As a result of the de-industrialization process, when the absence of human activity is obvious, the previously created architectural composition becomes destroyed. Open spaces are filling by the "spontaneous" compositional and unorganized nature, itescapes the general structure of architectural space. Most often spontaneous nature is negatively perceived by people, it indicates a drop of human activity and the absence of the human himself. The aim of eco-reurbanization is the inclusion of city spaces in architectural spaces based on ecological principles by giving a composite organization and the natural forms of the new function[16].

The future of underground architecture is inextricably linked with the building technologies development. Analysis shows that the optimal conditions for sustainable development and comfortable living in cities may be achieved when the underground 
facilities take $20-25 \%$ of the total urban space. There is a very great hope, that the underground building will not be limited just steel or monolithic reinforced concrete structures. There are a lot of solutions to increase the structural strength and at the same time to reduce material consumption.

\section{References}

1 E.B.Marcova,Architecton. Proceedings of Higher Education,38 (2016)

2 V.A. Nefedov, ABD: Architecture. Building. Design 6(46), 60-64 (2004)

3 http://vitruviosons.com/year/2004/kafe-v-Aleksandrovskom- parke/

4 http://www.astragaldesign.com

5 http://www.hljmuseum.com/system/201510/101925.html

6 Ge Peng,Some Analysis on Underground Architecture and its Advantages and Disadvantages (Liaoning Architectural Design and Research Institute, 2011)

7 L.W.Jie, N.X. Ping, C.B. Yi, Industrial Construction39,67 - 69 (2011)

8 Y.K.Ming,Journal of Sichuan University of Science and Technology20,23 - 26 (2000)

9 D. Fang, L. Yong, W. Feng, Electric \& Intelligent Building39, 68 - 70 (2011)

10 Zh.D.Ming, Underground Space22, 3 (2002)

11 W.L.Jun, J. Xiang, Research on Energy Conservation Strategies of Underground Buildings1,69 - 70(2009)

12 Y.Xue, L.D. Ping, Shanxi Architecture35, 19 - 20 (2014)

13 H.Fan, Underground Space4,1-9 (1988)

14 Z.A. Gaevskaya, Architecture and Modern Information Technology1, 18(2012)

15 Z.A. Gaevskaya, Architecture and Modern Information Technology 4,17(2011)

16 A.V. Voronina, Nizhny Novgorod State University of Architecture and Civil Engineering 1, 88-92(2012)

17 S. Paunović-Žarić, V. Radulović, E. Alihodžić-Jašarović, V. Murgul. Journal of Applied Engineering Science, 14(1), 140 - 147 (2016)

18 V. Murgul, D. Vuksanovic, V. Pukhkal, N. Vatin, Applied Mechanics and Materials, 633-634, 977-981 (2014)

19 I. Yamshanov, V. Goryunov, V, Murgul, Procedia Engineering, 117, 663-674 (2015) 